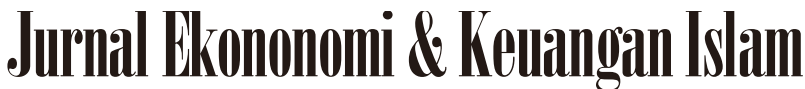

\author{
Available at http://journal.uii.ac.id/index.php/jeki
}

\section{Pengaruh Pembiayaan, Aset, dan FDR Perbankan Syariah terhadap Kesejahteraan Masyarakat di Indonesia}

\author{
Achmad Nurdany \\ Fakultas Ekonomi dan Bisnis UIN Sunan Kalijaga Yogyakarta \\ e-mail: achmad.nurdany@uin-suka.ac.id
}

\section{Keywords:}

sharia banking, welfare of society, IPM +, Kesejahteraan Masyarakat

DOI:

10.20885/JEKI.vol2.iss2.art1

\begin{abstract}
Bank Muamalat Indonesia (BMI) begins its operation on 1st May 1992 and since then the Islamic banking in Indonesia has continued showing rapid growth. As of June 2015, the number of Islamic banks in Indonesia has reached a total of 12 Sharia Commercial Banks (BUS), 22 Sharia Business Units (UUS), and 161 Sharia Rural Financing Banks (BPRS). Increasing the growth of Islamic banking in Indonesia is expected to encourage the nation's economy and increasing the welfare of Indonesian society. This study is arranged in order to analyze whether Islamic banking affects the welfare of Indonesian society or not, if Islamic banking has an impact if it's positive or negative. The public welfare from an Islamic perspective is measured using the Human Development Index (HDI +). HDI + is an index that can represent welfare according to Islamic perspective, where there are 5 components of maslahah consisting of religion, soul, intellectual, family, and property. The research result shows that individually, Islamic banking has impact with the welfare of Indonesian society based on Islamic perspective. Islamic banking financing has a significant positive effect, sharia banking asset variable has a significant negative effect, and the variable of FDR of sharia banking has no effect. Nevertheless, jointly financing variables, assets, and FDR of sharia banks have a significant effect on the welfare of society according to Islamic perspective in Indonesia.
\end{abstract}

\section{Pendahuluan}

Kiprah perbankan syariah di Indonesia telah ada sejak pertama kalinya Bank Muamalat Indonesia (BMI) beroperasi, yaitu pada tanggal 1 Mei 1992. Sebelum itu, wacana pendirian bank Islam sudah pernah dicetuskan dan secara resmi dibahas dalam forum yang bertepatan dengan dilaksanakannya Lokakarya Bunga Bank dan Perbankan bertempat di Cisarua, Bogor, Jawa Barat oleh Majelis Ulama Indonesia (MUI) pada tanggal 22 s/d 25 Agustus 1990 (Sudarsono, 2007).

Sejak saat itu, perbankan syariah terus mengalami pertumbuhan, sampai dengan Juni 2015 ini, jumlah perbankan syariah di Indonesia sudah mencapai totalnya 12 Bank Umum Syariah (BUS), 22 Unit Usaha Syariah (UUS), dan 161 Bank Pembiayaan Rakyat Syariah (BPRS). Dalam kurun waktu 13 tahun sejak pertama kali dicetuskan, pertumbuhan perbankan syariah di Indonesia dinilai cukup berkembang pesat. Salah satu faktor yang 
menyebabkan pertumbuhan tersebut adalah tingginya angka permintaan masyarakat akan sistem perbankan yang bebas dari unsur yang tidak diperbolehkan dalam Islam. Unsur-unsur yang tidak diperbolehkan dalam Islam adalah seperti riba, maisir, ghoror, ikhtikar, dan lain sebagainya.

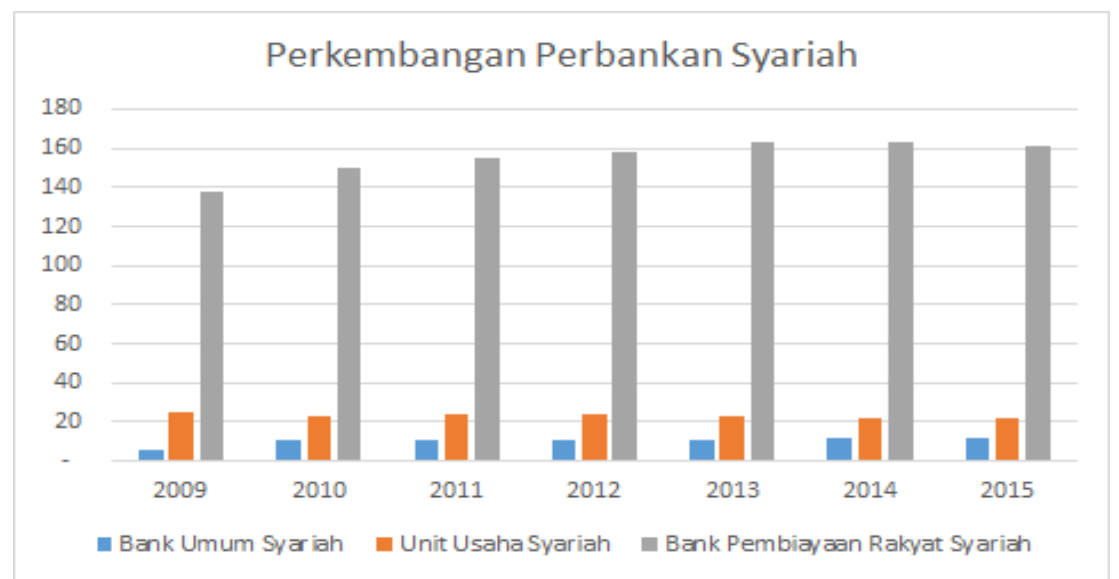

Sumber: OJK, Statistik Perbankan Syariah

Gambar 1. Perkembangan Perbankan Syariah

Sementara untuk jumlah kantornya, data terbaru Juni 2015 menjelaskan bahwa BUS memiliki 2.121 kantor, bank konvensional yang mengoperasikan UUS memiliki 327 kantor, dan BPRS memiliki 433 kantor. Gambar 2 di bawah ini menggambarkan perihal jumlah kantor perbankan syariah tersebut:

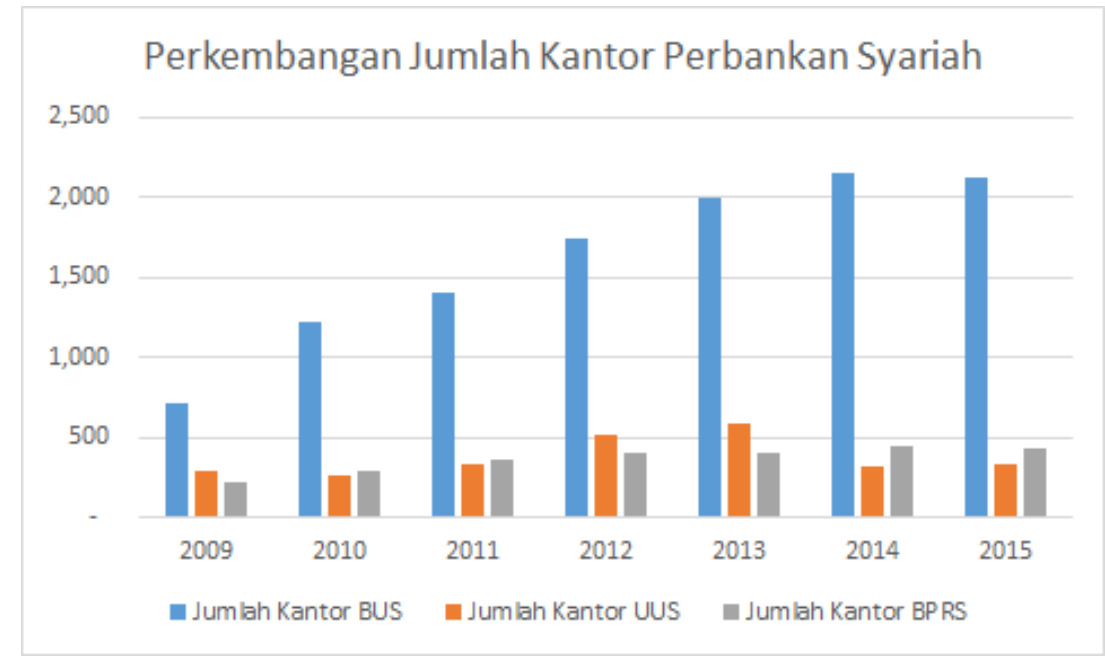

Sumber: OJK, Statistik Perbankan Syariah

Gambar 2. Perkembangan Jumlah Kantor Perbankan Syariah

Meningkatnya pertumbuhan perbankan syariah di Indonesia pada dasarnya juga diharapkan mampu mendorong perekonomian bangsa menjadi lebih baik. Pembahasan mengenai hal itu telah dilakukan oleh beberapa peneliti, seperti Abduh, Muhamad, dan Omar, (2012) yang menemukan adanya hubungan signifikan berkaitan dengan perkembangan keuangan Islam dan pertumbuhan ekonomi di Indonesia. Menurutnya hubungan tersebut adalah positif, artinya semakin bagus pertumbuhan keuangan Islam di Indonesia semakin baik pula pertumbuhan ekonominya.

Begitu juga dengan hasil penelitian Yazdan, Gudarzi F., dan Hossein, (2012) yang menjelaskan bahwa perbankan syariah di Iran dan Indonesia memiliki pengaruh positif signifikan terhadap pertumbuhan ekonomi dalam jangka pendek dan jangka panjang. Dalam penelitiannya, Yazdan \& Hossein (2012) juga menyarankan kepada pemerintah Indonesia untuk terus mendorong pertumbuhan perbankan syariah karena hal tersebut berdampak baik bagi pertumbuhan ekonomi secara umum. 
El-Galfy, Ahmed, dan Khiyar, (2012)dalam penelitiannya menjelaskan bahwa perbankan syariah dapat berpengaruh signifikan pada pertumbuhan ekonomi baik di negara maju maupun di negara berkembang. Melalui studi literatur yang dilakukannya, El-Galfy \& Khiyar mengemukakan bahwa perbankan syariah memiliki kontribusi yang porisitif terhadap pertumbuhan ekonomi, sehingga kebijakan-kebijakan stabilisasi makroekonomi sebaiknya memperhatikan hal tersebut. Sesuai dengan apa yang disarankan oleh penulis dalam penelitian tersebut, penelitian ini lebih memilih menggunakan data panel dari pada runtut waktu. Selain itu penelitian ini juga mengangkat variabel independen dengan variabel dependen yang lebih luas cakupannya, yaitu kesejahteraan masyarakat.

Sementara itu, Dusuki, (2008) menjelaskan bahwa sektor mikro finansial merupakan sektor yang sangat penting yang bisa mendorong upaya peningkatan kesejahteraan masyarakat, terutama golongan menengah ke bawah. Sektor ini membutuhkan pendekatan yang inovatif agar bisa tetap berada pada tujuan tersebut, salah satu yang menjadi sorotan adalah peran perbankan syariah, dimana menurutnya perbankan syariah merupakan salah satu solusi dalam rangka upaya mendorong peningkatan kesejahteraan masyarakat melalui sektor keuangan mikro. Penelitian ini diarahkan untuk mencari bukti empirik berupa data dan analisisnya atas teori yang sudah disampaikan, tujuannya untuk membuktikan kebenaran perbankan syariah sebagai alat untuk meningkatkan kesejahteraan rakyat.

Pengembangan sektor keuangan perbankan syariah juga ditemukan berpengaruh positif signifikan terhadap kesejaheraan rakyat yang diproksikan dengan pertumbuhan Produk Regional Domestik Bruto (PDRB) di Yordania pada periode 1980-2012 (Al-Oqool, Mohammed Ali, 2014). Menggunakan analisis Vector Error Correction Model (VECM), peneliti tersebut menjelaskan bahwa terdapat pula hubungan kausalitas jangka panjang antara perbankan syariah dengan PDRB Yordania dimana penelitian itu juga merefleksikan hubungan positif antara pembiayaan perbankan syariah dengan pembangunan kesejahteraan sosial dan ekonomi masyarakat di negara tersebut.

Penelitian ini menggunakan konsep yang sama, yaitu mencari hubungan pengaruh antara variabelvariabel perbankan syariah seperti pembiayaan, asset dan FDR dengan peningkatan kesejahteraan rakyat, penelitian ini mengambil tempat dan lokasi yang berbeda. Hasil dari penelitian ini bisa jadi mempunyai dua kemungkinan, pertama mendukung apa yang sudah ditemukan oleh peneliti sebelumnya, atau sebaliknya.

Selanjutnya Hassan (2014)dalam penelitiannya menemukan bahwa perananan sektor mikro finance terutama yang berbasiskan syariah secara kolektif dapat membantu masyarakat dalam membentuk perekonomian yang lebih sejahtera, meningkatkan kepedulian lingkungan, serta menjaga sumber daya yang dimiliki oleh para anggota. Secara umum temuan ini dimaksudkan untuk menggambarkan banyaknya tantangan dalam upaya mengurangi angka kemiskinan, sektor islamic microfinance diharapkan mampu berkontribusi terhadap upaya tersebut.

Berbeda dengan temuan tersebut, penelitian ini tidak berfokus pada sektor keuangan mikro, penelitian ini berfokus pada sektor perbankan syariah yang cakupannya lebih luas, menurut hemat penulis perbankan syariah sebenarnya juga memiliki hubungan langsung dengan sektor keuangan mikro seperti Baitul Mal wa Tamwil (BMT) yang saat ini sudah banyak berkembang di Indonesia.

Sedikit melebar dari penelitian sebelumnya, Choudhury, M Alam, dan Harahap, (2008) telah mengeksplorasi sebuah teori dimana zakat dan perbankan syariah sebenarnya memiliki hubungan yang mendalam dengan ekonomi secara riil. Menurutnya, hubungan tersebut dapat di formalisasikan melalui asumsi integrasi pengetahuan yang berdasarkan pada Al-Qur'an, Hadits, dan diskursus sosial. Penelitian ini mengangkat konsep yang sama terutama dari segi keterkaitan antara perbankan syariah dan kondisi ekonomi secara riil dengan menggunakan bukti empirik berupa data penelitian perbankan syariah dan kesejahteraan masyarakat di Indonesia.

Kemudian Andriansyah (2009) dalam penelitiannya menemukan bahwa setelah melakukan analisis pada data yang digunakan, ternyata perbankan syariah secara umum telah menunjukkan kinerja keuangan yang menggembirakan. Di samping itu perbankan syariah juga telah memberikan kontribusi penting bagi pembangunan nasional dengan melakukan fungsi intermediasi keuangan dan menjaga stabilitas keuangan nasional. Hal ini yang kemudian menjadi dasar pada penelitian ini apakah secara statistik, dengan data yang lebih luas yaitu per propinsi di Indonesia, terbukti kebenarannya bahwa perbankan syariah mampu memberikan kontribusi positif bagi pembangunan nasional khususnya dan kesejahteraan masyarakat pada umumnya. Nurzaman, (2011)juga pernah melakukan penelitian mengenai kesejahteraan masyarakat yang diukur menggunakan Indeks Pembangunan Manusia (IPM), namun yang berbeda adalah variabel independennya berupa zakat. Menurutnya zakat tidak berpengaruh signifikan secara statistik terhadap pembangunan manusia, namun yang menarik bahwa zakat ternyata dapat menggeser pola penerimaan masyarakat yang sebelumnya konsumtif menjadi lebih produktif. Dengan konsep yang sama penelitian ini mencoba mengganti variabel zakat dengan pembiayaan perbankan syariah kepada masyarakat, sehingga dampaknya bisa langsung dirasakan pada peningkatan kesejahteraan. 
Lebih lanjut lagi, penelitian mengenai perbankan syariah dan kesejahteraan masyarakat yang diukur dengan IPM pernah dilakukan secara langsung oleh Putri (2014). Ia menemukan bahwa ternyata ada pengaruh yang signifikan antara variabel pembiayaan bank syariah terhadap kesejahteraan di Indonesia pada tahun 20102012. Melengkapi temuan tersebut, penelitian ini menggunakan data yang lebih baru dan lebih luas (data panel tahun 2012-2014) yang tidak hanya terdiri dari pembiayan bank syariah saja, namun juga aset nya yang merepresentasikan pertumbuhan bank syariah tersebut.

Dari beberapa penelitian tersebut, ditemukan bahwa pertumbuhan perbankan syariah di Indonesia berdampak baik bagi perekonomian. Namun demikian peningkatan pertumbuhan ekonomi saja belum cukup untuk menggambarkan kondisi kesejahteraan masyarakat secara luas. Padahal sejatinya ruh dari pembentukan sistem ekonomi Islam (termasuk di dalamnya perbankan syariah) adalah untuk mencapai falah, yaitu sejahtera di dunia dan di akhirat.Berangkat dari permasalahan artikel dengan judul"Analisis Pengaruh Pembiayaan, Aset, Dan Fdr Perbankan Syariah Terhadap Kesejahteraan Masyarakat Di Indonesia” ini disusun dalam rangka meneliti apakah perbankan syariah berdampak terhadap kesejahteraan masyarakat di Indonesia atau tidak, kalau berdampak kemudian bagaimana pengaruhnya apakah positif atau negatif.

\section{Meode Penelitian}

Variabel dependen pada penelitian ini adalah tingkat kesejahteraan masyarakat Indonesia menurut perspektif Islam yang diwakili dengan data IPM+. Kemudian variabel independennya adalah pertumbuhan perbankan syariah yang diproksikan dengan pembiayaan yang disalurkan, aset yang dimiliki oleh perbankan syariah di Indonesia, serta rasio pembiayaan terhadap dana pihak ketiga.

Variabel dependen pada penelitian ini yaitu tingkat kesejahteraan masyarakat menurut perspektif islam (falah). Falah bisa dicapai dengan syarat masyarakat dapat memenuhi kebutuhan dasarnya yaitu maslahah yang terdiri kebutuhan agama, jiwa, intelektual, keturunan, dan harta. Kesejahteraan masyarakat dalam penelitian ini diwakili dengan variabel IPM+ yang tersusun dari IPM ditambah dengan indeks religiusitas dan indeks keluarga.

IPM+ merupakan sebuah indeks yang dapat merepresentasikan kesejahteraan menurut perspektif Islam, dimana di dalam IPM+ terdapat 5 komponen maslahah yang terdiri dari agama, jiwa, intelektual, keluarga, dan harta. Masing-masing penjelasan dari komponen maslahah tersebut adalah sebagai berikut:

1. Agama (ad-dien)

Idealnya komponen ini diukur menggunakan indikator jumlah umat muslim per 1000 penduduk, jumlah umat muslim yang menunaikan sholat lima waktu, jumlah tempat ibadah, jumlah pengeluaran untuk zakat, infaq, dan shodaqoh, serta persentase jumlah jamah haji. Kelima hal tersebut merupakan kewajiban (beberapa termasuk sunnah) yang harus dilakukan oleh umat muslim.

Namun demikian dikarenakan keterbatasan data yang ada saat ini, maka penulis hanya memasukkan komponen jumlah jamaah haji masing-masing provinsi selama kurun waktu penelitian. Indikator ini dihitung menggunakan rumus ini:

$$
\text { Dimensi Religiusitas }=I_{\text {Religiusitas }}=\frac{J J H-J J H_{\min }}{J J H_{\max }-J J H_{\min }} \times 100
$$

Keterangan: JJH = Jumlah Jamaah Haji

Meskipun disadari Indeks Religiusitas ini masih memiliki keterbatasan tetapi diharapkan dapat mewakili ukuran kesejahteraan masyarakat menurut perspektif Islam yang dilihat dari aspek maslahah yang pertama yaitu kesejahteraan agama.

2. Jiwa (an-nafs)

Pada dasarnya jiwa merupakan representasi dari diri sendiri baik secara fisik maupun non fisik, individual maupun sosial, material maupun spiritual. Untuk mengukur komponen ini penulis menggunakan indikator umur yang panjang dan sehat yang sudah terangkum dalam IPM sebagai representasi dari komponen maslahah kedua yaitu kesejahteraan jiwa.

Indeks yang digunakan adalah Indeks Kesehatan dengan indikator Angka Harapan Hidup masyarakat Indonesia

3. Intelektual ( $a l$ - 'aql)

Intelektual merupakan tingkat pemahaman seseorang mengenai berbagai macam hal, meskipun tidak sepenuhnya benar tetapi komponen ini bisa diukur menggunakan indikator Angka Harapan Sekolah dan Rata-rata Lama Sekolah. Kedua indikator tersebut juga sudah disertakan dalam perhitungan IPM metode baru saat ini, penulis meyakini bahwa Indikator IPM yang digunakan terutama Dimensi Pendidikan dapat mewakili ukuran kesejahteraan menurut perspektif Islam berdasarkan maslahah yang ketiga yaitu kesejahteraan akal/intelektual.Indeks yang digunakan adalah Indeks Pendidikan dengan indikator Angka Harapan Lama Sekolah dan Rata-rata Lama Sekolah. 
4. Keluarga dan keturunan (an-nasl)

Indikator sebuah keluarga/keturunan yang sejahtera salah satunya dapat dilihat dari banyaknya angka pernikahan yang ada dimasyarakat. Angka pernikahan yang semakin tinggi disebuah wilayah mempunyai arti bahwa kesejahteraan keluarga di wilayah tersebut juga semakin besar. Dengan demikian penulis menggunakan indikator Angka Pernikahan masing-masing provinsi di Indonesia sebagai representasi dari komponen maslahah yang keempat yaitu kesejahteraan keluarga. Komponen ini dapat dihitung dengan rumus berikut:

$$
\text { Dimensi Keluarga }=I_{\text {Keluarga }}=\frac{A P-A P_{\min }}{A P_{\max }-A P_{\min }} \times 100
$$

Keterangan : AP = Angka Pernikahan

Meskipun masih memiliki keterbatasan namun Indeks Keluarga dengan indikator Angka Pernikahan ini diharapkan dapat mewakili kesejahteraan keluarga menurut perspektif Islam.

5. Materi (al-mal)

Berikutnya adalah komponen kesejahteraan menurut perspektif Islam berdasarkan pada indikator maslahah yang kelima yaitu materi. Pada dimensi ini ukuran kesejahteraan materi seseorang sudah dimasukkan dalam IPM metode baru dimana indikatornya adalah Pengeluaran Perkapita masyarakat.

Indeks yang digunakan adalah Indeks Pengeluaran dengan indikator Pengeluaran Perkapita Masyarakat.

Selanjutnya IPM+ dihitung berdasarkan rata-rata dari penambahan IPM dengan indeks kesejahteraan agama dan dan indeks kesejahteraan keluarga. Dengan demikian rumus perhitungan IPM+ tersebut adalah sebagai berikut:

$$
\mathrm{IPM}+=3 / 5 \mathrm{IPM}+1 / 5 \mathrm{I}_{\text {Religiusitas }}+1 / 5 \mathrm{I}_{\text {Keluarga }}
$$

Rumus di atas didasarkan pada penelitian yang pernah dilakukan oleh Anto (2011) mengenai Indeks Pembangunan Manusia Islam. Anto memaparkan bahwa IPM Islam tersusun berdasarkan dua kategori besar, yaitu Main Index dan Additional Index. Main Index terdiri dari faith, life, science, family social, dan property index. Sedangkan Additional Index terdiri dari freedom dan environment index. IPM Islam juga disusun berdasarkan lima mashlahah dasar kehidupan manusia di antaranya agama, jiwa, inteletktual, keluarga, dan materi.Rumus yang sama juga dijelaskan oleh Feriyanto (2014) tentang IPM, menurutnya IPM tersusun dari pembagian rata-rata antara Indeks Pengeluaran, Indeks Kesehatan, dan Indeks Pendidikan.

Dari penjelasan di atas, dapat disimpulkan bahwa ukuran kesejahteraan masyarakat menurut perspektif Islam, yang direpresentasikan dalam Indeks Pembangunan Manusia Plus (IPM+), telah memuat lima dimensi utama maslahah yaitu agama, jiwa, intelektual, keluarga, dan materi. Komponen dan indikator dari IPM+ secara rinci dapat dilihat pada gambar berikut:

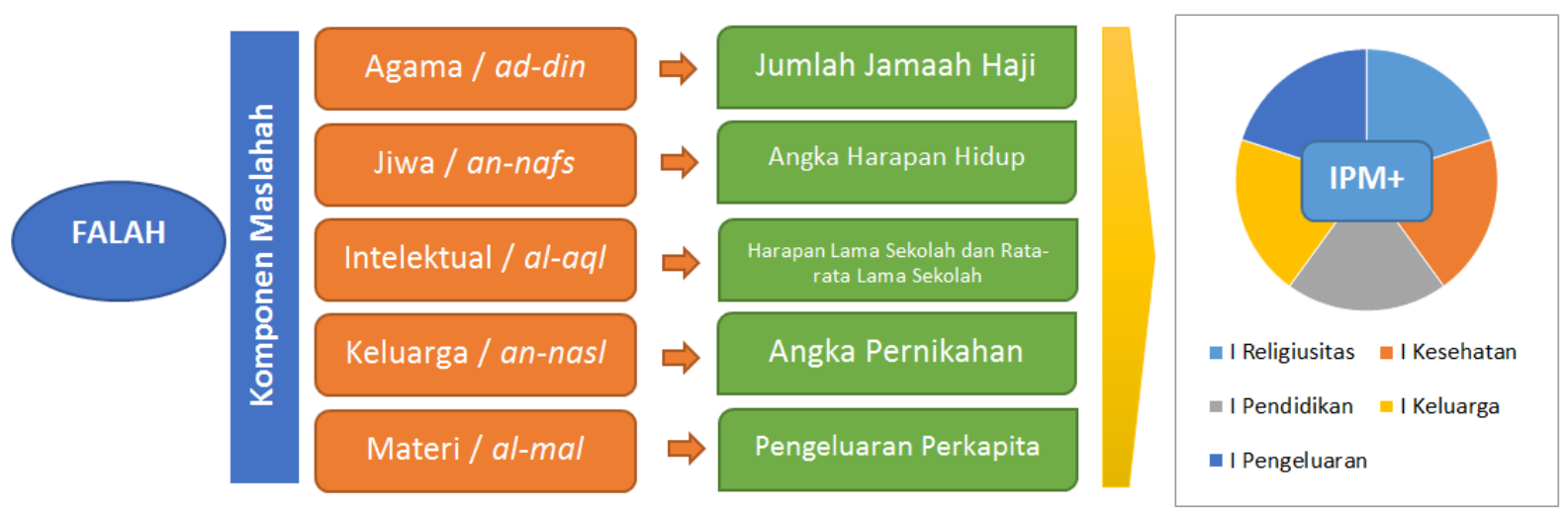

Gambar 3. Komponen dan Indikator IPM+ terdiri dari:

Variabel independen pada penelitian ini adalah pertumbuhan perbankan syariah di Indonesia, yang

a. Pembiayaan Perbankan Syariah. Merupakan jumlah total pembiayaan yang disalurkan oleh perbankan syariah di Indonesia kepada masyarakat, diproksikan dengan X1 
b. Aset Perbankan Syariah

Merupakan jumlah total aset yang dimiliki oleh perbankan syariah (baik BUS maupun UUS) yang diproksikan dengan X2

c. Finance to Deposit Ratio

Merupakan rasio pembiayaan yang disalurkan oleh perbankan syariah terhadap dana pihak ketiga yang masuk, diproksikan dengan X3.

\section{Metode Analisis Data}

Metode analisis data pada penelitian ini menggunakan teknik regresi data panel (pooled), hal ini dilakukan karena data penelitian ini menggunakan gabungan antara data antar waktu dan antar individu.

Model persamaan regresi pada penelitian ini adalah sebagai berikut:

$$
Y_{i t}=\beta_{0}+\beta_{1} X_{1 t}+\beta_{2} X_{2 t}+\beta_{3} X_{3 t}+e
$$

Dimana $Y_{i t}$ merupakan nilai dari IPM+ padat tahun t. $\beta_{0}$ adalah konstanta regresi. $\beta_{1}, \beta_{2}, \beta_{3}$ adalah koefisien regresimasing-maisng variabel. $X_{1 t}, X_{2 t}$, dan $X_{3 t}$ masing-masing merupakan asset, pembiayaan dan Finance to Deposit Ratio pada perbankan syariah di Indonesia.

Penelitian ini menggunakan data yang terdiri dari statistik perbankan syariah, angka penikahan, jumlah jamaah haji, dan indeks pembangunan manusia dari 33 Provinsi di Indonesia selama kurun waktu 2012 s/d 2014. Penentuan penggunaan variabel independen dan dependen dengan model linier atau log linier pada penelitian ini menggunakan uji MWD (Mackinnon, White, dan Davidson). Penggunaan metode ini disesuaikan dengan perilaku data ekonomi apakah memiliki hubungan linier atau non-linier dalam parameter. Ada dua cara penentuan pemilihan model yaitu menggunakan: (1) metode informal dengan mengetahui perilaku data melalui skettergram; (2) metode formal yang dikembangkan oleh Mackinnon, White, dan Davidson yang juga digunakan dalam penelitian ini.

Penentuan penggunaan variabel independen dan dependen didasarkan pada kesimpulan dalam pengambilan keputusan uji MWD berikut ini: apabila Z1 signifikan secara statistik maka model yang baik digunakan untuk penelitian ini adalah model log linier, begitu pula sebaliknya apabila Z2 signfikan secara statistik maka model yang baik digunakan untuk penelitian ini adalah model linier, begitu pula sebaliknya.

\section{Hasil dan Pembahasan}

Dalam estimasi model data panel, dikenal tiga macam pendekatan estimasi yaitu pendekatan common effect, fixed effect, dan random effect. Langkah pertama melakukan teknik yang paling sederhana untuk mengestimasi data panel adalah dengan menggabungkan data time series dan cross section, metode yang bisa digunakan adalah Ordinary Least Square (OLS). Metode ini disebut juga dengan estimasi common effect, dalam estimasi ini diasumsikan bahwa perilaku data antar individu adalah sama dalam berbagai kurun waktu.Berikutnya yang perlu dilakukan adalah mengestimasi data panel dengan menggunakan metode yang lainnya untuk memastikan metode mana yang terbaik yang bisa digunakan dalam penelitian dengan Uji Signifikansi Fixed Effect, Uji ini digunakan untuk mengetahui apakah model regresi data panel menggunakan fixed effect lebih baik dari pada model regresi menggunakan common effect. Berikut adalah hasil dari uji signifikansi fixed effect dalam penelitian ini:

Tabel 1. Hasil Uji Signifikansi Fixed Effect

\begin{tabular}{cccc}
\hline Effects Test & Statistic & d.f. & Prob. \\
\hline Cross-section F & 1.272334 & $(32,63)$ & 0.2052 \\
Cross-section Chi-square & 49.352393 & 32 & 0.0257 \\
\hline
\end{tabular}

Sumber: Data diolah

Dasar pengambilan keputusan yang digunakan untuk menentukan model mana yang lebih baik adalah sebagai berikut: apabila probabilitas lebih besar dari $0,05(\alpha=5 \%)$ atau hasilnya tidak signifikan maka model regresi menggunakan metode common effect adalah lebih baik dan apabila probabilitas lebih kecil dari $0,05(\alpha=$ $5 \%$ ) atau hasilnya signifikan maka model regresi menggunakan metode fixed effect adalah lebih baik.

Probabilitas uji signifikansi fixed effect adalah 0,2052 dan lebih besar dari pada 0,05 ( $\alpha=5 \%)$, maka berdasarkan pada ketentuan dasar pengambilan keputusan di atas, dapat disimpulkan bahwa model regresi menggunakan metode common effect adalah lebih baik.Apabila di dalam uji signifikansi fixed effect ditemukan kesimpulan bahwa model regresi menggunakan metode fixed effect lebih baik, maka yang perlu dilakukan selanjutnya adalah melakukan analisis menggunakan metode random effect, dan melakukan uji signifikansi 
random effect. Akan tetapi dikarenakan hasil uji signifikansi fixed effect pada penelitian ini menyatakan bahwa model regresi menggunakan metode common effect adalah lebih baik, maka langkah-lankah berikutnya tidak perlu dilakukan. Hasil regresi Common Effect sebagai berikut:

Tabel 2. Hasil Estimasi Data Panel Metode Common Effect

\begin{tabular}{crrrr}
\hline Variable & Coefficient & Std. Error & t-Statistic & Prob. \\
\hline C & 41.4899 & 1.3757 & 30.1576 & 0.0000 \\
X1 & 0.0032 & 0.0002 & 15.6440 & 0.0000 \\
X2 & -0.0011 & $7.81 \mathrm{E}-05$ & -14.4410 & 0.0000 \\
X3 & -0.0108 & 0.0099 & -1.0849 & 0.2807 \\
\hline
\end{tabular}

Sumber: Data diolah

Hasil regresi menunjukkan koefisien determinasi $\mathrm{R}^{2}$ pada model regresi yang menggunakan metode common effect pada penelitian ini adalah $0.7535(75,35 \%)$. Hal ini menunjukkan bahwa variabel independen yang dimasukkan kedalam model dapat mempengaruhi variabel dependen sebesar 75,35 persen, sedangkan sisanya adalah variabel yang sebenarnya memiliki pengaruh namun tidak dimasukkan kedalam model. Dalam arti lainnya, pembiayaan, aset dan FDR perbankan syariah pada penelitian ini mampu menjadi faktor yang mempengaruhi kesejahteraan masyarakat di Indonesia sebesar 75,35 persen.

Berdasrkan tabel 2 dapat dilihat pengaruh variabel independen terhadap variabel dependen dengan menggunakan derajat signifikansi 5\%, hanya variabel pembiayaan dan asset. Untuk variabel Pembiayaan perbankan syariah memiliki koefisien bertanda positif, nilai t-statistik 15.64405 , dan probabilitas 0.00000 . Dengan demikian dapat disimpulkan bahwa variabel Pembiayaan perbankan syariah berpengaruh positif signifikan terhadap kesejahteraan masyarakat menurut perspektif Islam di Indonesia. Variabel Aset perbankan syariah memiliki koefisien bertanda negatif, dengan nilai t-statistik -14.44103, dan probabilitas 0.00000 . Dengan demikian dapat disimpulkan bahwa variabel Aset perbankan syariah berpengaruh negatif signifikan terhadap kesejahteraan masyarakat menurut perspektif Islam di Indonesia.Hasil olah data penelitian menunjukkan bahwa konstanta regresi adalah 41.48997 dimana dapat diinterpretasikan bahwa jika variabel independen yang berupa Pembiayaan, asset, dan FDR perbankan syariah sama dengan nol, maka kesejahteraan masyarakat menurut perspektif Islam di Indonesia nilainya adalah 41.48

Uji Statistik F dilakukan dengan tujuan untuk mengetahui apakah variabel independen secara serempak (simultan) berpengaruh terhadap variabel dependen. Hasil olah data penelitian bahwa probabilitas statistik $\mathrm{F}$ adalah 0.0000 maknanya secara keseluruhan dan bersama-sama variabel independen dalam penelitian ini memiliki pengaruh yang signifikan terhadap variabel independen. Dengan kata lain, variabel pembiayaan, aset, dan FDR perbankan syariah secara bersamaan berpengaruh terhadap kesejahteraan masyarakat menurut perspektif Islam di Indonesia.

\section{Variabel Pembiayaan}

Intrepetasi ekonomi dari hasil olah data menjelaskan fenomena variabel perbankan syariah apa saja yang mempengaruhi kesejahteraan masyarakat menurut perspektif Islam. Di samping itu juga untuk mengetahui mengapa variabel tersebut berpengaruh/tidak berpengaruh, berapa besar pengaruhnya, serta perbandingan dengan penemuan penelitian sebelumnya. Berdasarkan hasil penelitian ditemukan bahwa variabel pembiayaan bank syariah berpengaruh positif signifikan terhadap kesejahteraan masyarakat menurut perspektif Islam (IPM+). Koefisien regresi sebesar 0.003205 menunjukkan bahwa apabila variabel pembiayaan syariah meningkat 1 Juta Rupiah maka akan menyebabkan peningkatan pada kesejahteraan masyarakat menurut perspektif Islam (IPM+) sebesar 0.003205 begitu juga sebaliknya.Pembiayaan yang disalurkan kepada masyarakat oleh perbankan syariah akan berpengaruh pada peningkatan produksi barang, pengolahan bahan baku, volume perdagangan, dan atau pelaksanakan kegiatan ekonomi lainnya oleh mitra (pengusaha) yang mengajukan pembiayaan. Peningkatan pada pembiayaan perbankan syariah akan menyebabkan tukar menukar barang dan jasa di masyarakat juga semakin meningkat, kegiatan ekonomi yang meningkat dapat dapat mengangkat kesejahteraan masyarakat dari segi ekonomi. Sedangkan jika melihat kesejahteraan dari segi yang lain, religiusitas misalnya, masyarakat yang mendapatkan pembiayaan di perbankan syariah akan lebih merasa nyaman karena terbebas dari hal-hal yang dilarang dalam Islam. Kenyamanan yang dirasakan oleh masyarakat dalam menggunakan pembiayaan bank syariah tersebut bisa juga dikategorikan sebagai kesejahteraan batin, atau kesejahteraan agama.

Beberapa penelitian di bawah ini mendukung hasil bahwa pembiayaan perbankan syariah memiliki kontribusi positif terhadap kesejahteraan masyarakat. Abduh, Muhamad, dan Omar, (2012) dalam penelitiannya 
telah menemukan bahwa kegiatan usaha pada perbankan syariah termasuk didalamnya pembiayaan yang disalurkan berpengaruh terhadap kesejahteraan masyarakat. Kesejahteraan masyarakat pada penelitian tersebut diukur menggunakan pertumbuhan ekonomi, dimana data penelitian berupa data tiga bulanan perbankan syariah di Indonesia, dengan menggunakan metode Error Correction Model (ECM) yang dikembangkan dengan Autoregressive Distributed Lag (ARDL). Penelitian tersebut memandang adanya kebutuhan untuk melihat kembali regulasi dan pedoman perbankan syariah jika ingin berkembang pesat di seluruh dunia. Andriansyah (2009)dalam penelitiannya juga menemukan hal yang sama, dengan mengkaji obyek penelitian di Indonesia, ditemukan bahwa kinerja keuangan perbankan syariah di Indonesia memiliki kontribusi positif terhadap kesejahteraan masyarakat. Perbankan syariah di Indonesia secara umum telah menunjukkan kinerja keuangan yang menggembirakan. Di samping itu perbankan syariah juga telah memberikan kontribusi penting bagi pembangunan nasional dengan melakukan fungsi intermediasi keuangan dan menjaga stabilitas keuangan nasional. Penelitian tersebut juga menuntut partisipasi aktif pembiayaan syariah pada sektor primer di Indonesia dan mempraktekkan prinsip syariah terutama bagi hasil dalam operasionalnya.El-Galfy, Ahmed, dan Khiyar, (2012) dalam penelitiannya dengan menggunakan studi literature menjelaskan bahwa peran pembiayaan perbankan syariah dapat berpengaruh signifikan pada kesejahteraan masyarakat yang diukur menggunakan pertumbuhan ekonomi baik di negara maju maupun di negara berkembang. Menurutnya, kebijakan-kebijakan stabilisasi makroekonomi sebaiknya memperhatikan pengaruh perbankan syariah terhadap pertumbhan ekonomi tersebut. Sebagai implikasinya penelitian trersebut memberikan saran kepada pemerintah untuk mendukung upaya peningkatan perbankan syariah baik di negara maju maupun di negara berkembang.

Pembiayaan pada perbankan syariah juga ditemukan berpengaruh positif signifikan terhadap kesejaheraan rakyat yang diproksikan dengan pertumbuhan Produk Regional Domestik Bruto (PDRB) di Yordania pada periode 1980-2012 oleh Al-Oqool, Okab, \&Bashayreh (2014). Menggunakan analisis Vector Error Correction Model (VECM), peneliti juga menjelaskan bahwa terdapat hubungan kausalitas jangka panjang antara perbankan syariah dengan kesejahteraan masyarakat Yordania. Sebagai rekomendasinya penulis mengharapkan adanya peningkatan investasi pada sektor perbankan syariah dengan cara mendorong manajer perbankan syariah aktif mengenalkan instrumen-instrumen keuangan kepada masyarakat.

\section{Variabel Aset}

Berdasarkan hasil penelitian ditemukan bahwa variabel aset bank syariah berpengaruh negatif signifikan terhadap kesejahteraan masyarakat menurut perspektif Islam (IPM+). Koefisien regresi sebesar $-0,001127$ menunjukkan bahwa apabila variabel pembiayaan syariah meningkat 1 unit (Juta Rupiah) maka akan menyebabkan penurunan pada kesejahteraan masyarakat menurut perspektif Islam (IPM+) sebesar 0,001127 begitu juga sebaliknya.Pendapatan yang diterima oleh perbankan syariah apabila tidak disalurkan dalam bentuk pembiayaan ataupun produk lainnya, kemungkinan besar akan dialokasikan untuk penambahan aset. Porsi pembelian aset oleh bank syariah (kategori non pembiayan) yang semakin banyak tentunya akan menurunkan porsi jumlah pembiayaan yang disalurkan. Semakin besar aset yang dimiliki bank syariah akan berpengaruh negatif terhadap arus perputaran barang dan jasa yang ada di masyarakat, dan kemudian akan diikuti penurunan pada kesejahteraan masyarakat. Hal itu bisa terjadi karena produksi barang, pengolahan bahan baku, volume perdagangan, dan atau pelaksanakan kegiatan ekonomi lainnya oleh mitra (pengusaha) yang mengajukan pembiayaan ke bank syariah semakin sedikit. Artinya bank syariah lebih memilih untuk melakukan penambahan jumlah aset dibandingkan dengan menyalurkan dananya kepada masyarakat dalam bentuk pembiayaan atau pun produk lainnya.

Tidak banyak ditemukan penelitian pendukung yang secara khusus membahas pengaruh negatif variabel aset perbankan syariah terhadap kesejahteraan masyarakat ataupun pertumbuhan ekonomi. Namun demikian variabel aset yang semakin meningkat mengandung pengertian bahwa variabel-variabel yang lain seperti pembiayaan dan dana lainnya yang digulirkan kepada masyarakat akan semakin sedikit. Menurut Noor, Mohamad ANM \& Bt Ahmad (2011)bank dengan profitabilitas yang tinggi adalah bank yang memiliki biaya pengeluaran lebih tinggi dari pada aset yang dimiliki, memiliki lebih banyak modal daripada aset yang dimiliki, serta memiliki lebih banyak pengaruh ekonomi kepada masyarakat secara langsung. Hal ini sama artinya dengan perbankan syariah yang memiliki aset lebih banyak akan tidak banyak berdampak atau bahkan berdampak negatif pada kesejahteraan masyarakat menurut perspektif Islam.

\section{Kesimpulan}

Berdasarkan hasil analisis data penelitian yang telah dilakukan, dapat diambil kesimpulan) bahwa secara individu variabel pembiayaan perbankan syariah berpengaruh positif signifikan terhadap kesejahteraan masyarakat menurut perspektif Islam di Indonesia. Artinya peningkatan variabel perbankan syariah mampu memberikan kontribusi positif dan signifikan terhadap peningkatan kesejahteraan masyarakat (falah)di 
Indonesia.Kontribusi positif tersebut bisa terjadi karena pembiayaan yang disalurkan mampu meningkatkan kegiatan produksi barang, pengolahan bahan baku, volume perdagangan, dan atau pelaksanakan kegiatan ekonomi lainnya oleh mitra (pengusaha) yang mengajukan pembiayaan. Sedangkan jika melihat kesejahteraan dari segi religiusitas, masyarakat yang mendapatkan pembiayaan di perbankan syariah akan lebih merasa nyaman karena terbebas dari hal-hal yang dilarang dalam Islam. Kenyamanan yang dirasakan oleh masyarakat dalam menggunakan pembiayaan bank syariah tersebut bisa juga dikategorikan sebagai kesejahteraan batin, atau kesejahteraan agama.

Variabel aset perbankan syariah berpengaruh negatif signifikan terhadap kesejahteraan masyarakat menurut perspektif Islam di Indonesia. Pengaruh negatif ini bisa terjadi karena pendapatan yang diterima oleh perbankan syariah apabila tidak disalurkan dalam bentuk pembiayaan ataupun produk lainnya, kemungkinan besar akan dialokasikan untuk penambahan aset. Porsi pembelian aset oleh bank syariah (kategori non pembiayan) yang semakin banyak tentunya akan menurunkan porsi jumlah pembiayaan yang disalurkan. Peningkatan aset perbankan syariah dapat menyebabkan porsi pembiayaan yang disalurkan kepada masyarakat menjadi menurun sehingga kesejahteraan falah juga menurun. Hal itu bisa terjadi karena produksi barang, pengolahan bahan baku, volume perdagangan, dan atau pelaksanakan kegiatan ekonomi lainnya oleh mitra (pengusaha) yang mengajukan pembiayaan ke bank syariah semakin sedikit.

Hasil penelitian ini menggambarkan bahwa perkembangan perbankan syairah dapat mempengaruhi kesejahteraan masyarakat di Indonesia, di mana kesejahteraan tersebut tidak hanya di dunia saja melainkan juga kesejahteraan holistik. Sehingga dari sini pemerintah dapat memberikan perhatian lebih terkait dengan perkembangan perbankan syariah apabila ingin menciptakan kondisi masyarakat yang sejahtera secara lahir dan batin.

\section{Daftar Pustaka}

Abduh, Muhamad, dan Omar, M. A. (2012). Islamic Banking and Economic Growth. International Journal of Islamic and Middle Eastren Finance and Management, 5(1), 35-47.

Al-Oqool, Mohammed Ali, D. (2014). Financial Islamic Banking Development and Economic Growth: A Case Study of Jordan. International Journal of Economic and Finance, 6(3), 72.

Andriansyah, Y. (2009). Islamic Banking Performance in Indonesia and Its Contribution to National Development (No. 5840).

Choudhury, M Alam, dan Harahap, S. S. (2008). Interrelationship between Zakat, Islamic Bank, and the Economy, a Theoritical Exploration. Managerial FInance, 34(9), 610-617.

Dusuki, A. W. (2008). Banking for the Poor: The Role of Islamic Banking in Microfinance Initiatives. Humanomics, 24(1), 49-66.

El-Galfy, Ahmed, dan Khiyar, K. A. (2012). Islamic Banking and Economic Growth: A Review. The Journal of Applied Business Research, 28(5), 943.

Hassan, A. (2014). The Challenge in Poverty Allevation: Role of Islamic Microfinance and Social Capital. Humanomicscs, 30(1), 76-90.

Noor, Mohamad ANM \& Bt Ahmad, N. H. (2011). Relationship between Islamic Banking Profitability and Determinants of Efficiency. The IUP Journal Of Mahanegrial Economics, 9(3), 44.

Nurzaman, M. S. (2011). Zakat and Human Development: Empirical Analysis on Poverty Allevation in Jakarta Indonesia.8th International Conference on Islamic Economics and Finance.

Sudarsono, H. (2007). Bank dan Lembaga Keuangan Lainnnya. Yogyakarta: Ekonesia.

Yazdan, Gudarzi F., dan Hossein, S. S. (2012). Analysis of Islamic Bank's Financing and Economic Growth: Case Study Iran and Indonesia. Journal of Economic Cooperation and Development, 33(4), 1-24. 